\title{
Analysis of the $3^{\prime}$ end regions of the GDF9 and BMPR1B genes in Blackbelly sheep from Yucatán, Mexico
}

\author{
Rosa B. López-Ramírez¹, Héctor F. Magaña-Sevilla, Roberto Zamora- \\ Bustillos $^{1}$, Julio P. Ramón-Ugalde ${ }^{1}$, and Daniel González-Mendoza ${ }^{2}$ \\ ${ }^{1}$ División de Estudios de Posgrado e Investigación, Instituto Tecnológico de Conkal. Avenida Tecnológico, \\ C.P. 97345 , Conkal, Yucatán, Mexico. \\ ${ }^{2}$ Universidad Autónoma de Baja California, Instituto de Ciencias Agrícolas. Carretera a Delta s/n, Código \\ Postal 21705, Ejido Nuevo León - Baja California, Mexico.
}

\begin{abstract}
R.B. López-Ramírez, H.F. Magaña-Sevilla, R. Zamora-Bustillos, J.P. Ramón-Ugalde and D. González-Mendoza. 2014. Analysis of the regions 3' ends of the GDF9 and BMPR1B genes in the Blackbelly sheep from Yucatan, Mexico. Cien. Inv. Agr. 41(1): 123-128. The FecB mutation in the BMPR1B gene and the G6, G7 and G8 mutations in the GDF9 gene have been documented in Booroola Merino sheep breeds. These mutations have all been identified in several ovine breeds, such as Belclare, Cambridge. Blackbelly hairy sheep breed, which is well adapted to tropical climates due to its African origin, have 2 to 3 lambs per litter, corresponding to a high prolificacy for a tropical breed. The objective of this investigation was to identify mutations in the cDNA of the BMPR1B and GDF9 genes of 20 Blackbelly ewes selected for their prolificacy (two or more lambs by birth). The results of this study indicate the absence of mutations in these genes from the Blackbelly breed. However, it is important to analyze the 3' end region of the cDNA of these genes to rule out the presence or absence of other mutations related to prolificacy.
\end{abstract}

Key words: Blackbelly Breed, cDNA, FecB, 3' PCR-RACE.

\section{Introduction}

The Barbados Blackbelly is breeds of hairy sheep from the Caribbean island of Lesser Antilles with the characteristics of high prolificacy, high tolerance to infestation by internal parasites, favorable maternal traits and constant reproductive cycles (McClean et al., 2011). Due to these reproductive benefits, Blackbelly ewes are frequently used

Received September 2, 2013. Accepted February 27, 2014. Corresponding author: roberto.zamora@itconkal.edu.mx for maternal breeding or in crosses to produce F1 females with good reproduction rates. High prolificacy rates in sheep, which could be of great interest to breeders, are found in genes that have been investigated and identified in several other breeds (Davis, 2006). Favorable selection of these genes through QTLs could potentially increase the number of lambs born per litter.

The BMPR1B (Bone Morphogenetic Protein Receptor 1B) gene with a coding sequence of 10 exons has been mapped to sheep chromosome 6 
(Mulsant et al., 2001). The FecB mutation in BM$\mathrm{PR} 1 \mathrm{~B}$ consists of an $\mathrm{A} \rightarrow \mathrm{G}$ transition at nucleotide 746 in the open reading frame and is associated with the hyper-prolific phenotype of the Booroola sheep (Wilson et al., 2001; Souza et al., 2001). This mutation was subsequently reported in other sheep breeds around the world, including the Garole sheep (Polley et al., 2010), Japanese sheep (Davis et al., 2002), the Small Tailed Han sheep (Chu et al., 2007), Hu sheep (Wang et al., 2003) and others (Davis et al., 2006; Hua and Yang 2009). The GDF9 (Growth Differentiation Factor 9) gene maps to chromosome 5 and contains 2 exons (Bodensteiner et al., 1999). The gene extends through a genomic region of approximately $2.5 \mathrm{~kb}$ and contains two exons coding for one pro-peptide of 453 amino acids separated by a single intron of 1126 base pairs. In 2004, eight single base mutations (SNP) in the GDF9 gene (G1 to G8) were reported in Cambridge and Belclare ewes (Hanrahan et al., 2004). One mutation is located in exon 1 , one is located in an intron and six mutations are in exon 2. Three SNPs do not alter the amino acid sequence; these SNPs are located at position 471 (G2), position 477 (G3) and position 978 (G5). Five of these SNPs result in a change of amino acid sequences (G1, G4, G6, G7 and G8).The objective of this investigation was to identify mutations in the BMPR1B and GDF9 cDNA sequences obtained from 20 Blackbelly ewes selected for their prolificacy.

\section{Materials and methods}

\section{Isolation of total RNA}

Full blood Blackbelly ewes were selected from the breeding nucleus of Tecnológico de Conkal based on the number of lambs per birth. Twenty of those with a record of two or more lambs in each farrowing were used. Estrus was induced in these ewes over a period of 12 days by applying vaginal sponges impregnated with Chronogest ${ }^{\circledR}$ CR 7 (Flugestone acetate-acetosi- $\alpha$-fluoro-11- $\beta$ hidroxi-pregn-4-ene-3, 20 diona). Two days later, these females were sedated with Ketamin $(1.1 \mathrm{~mL}$
$50 \mathrm{~kg}^{-1}$ ) for quirurgical intervention, and ovarian tissue was biopsied. These biopsies were preserved in RNAlater and stored at $-20^{\circ} \mathrm{C}$ before being placed in $0.5 \mathrm{~mL}$ of TRIzol reagent (Invitrogen, Carlsbad CA) to be stored at $4{ }^{\circ} \mathrm{C}$ overnight. Total RNA was isolated by phase separation and precipitation following the manufacturer's standard protocol.

\section{cDNA cloning and 3'PCR-RACE}

Approximately $200 \mathrm{ng}$ total RNA from the ovarian tissue biopsies was converted into cDNA using Superscript II reverse transcriptase (Invitrogen) with a 3' RACE Adapter (5'-GCGAGCACAGAATTAATACGACTCACTATAGGT12 VN-3'), as specified in the FirstChoice ${ }^{\circledR}$ RLM-RACE kit. Two forward primers (AF, G7F) and one reverse adapter primer (3' RACE outer primer) were used for PCR-RACE. Two forward primers (AF, G7F) were designed on the basis of conserved sequences in the open reading frames (ORFs) of the BMPRIB gene and GDF9, respectively: AF, 5'-GTCGCTATGGGGAAGTTTGGATG-3'; G7F, 5'- GCCTCTGGTTCCAGCTTCAGTC-3'. The reverse 3' RACE outer primer was a shorter version of the 3' RACE adapter primer without the poly dT tail: 5'-GCGAGCACAGAATTAATACGACT-3' (Adapter). Primer pairs AF-3' RACE Outer and G7F-3' RACE Outer were used for PCR amplifications, which were performed in a total volume of $50 \mu \mathrm{L}$ containing $2 \mu \mathrm{L}$ of cDNA, 10X PCR buffer, $1.5 \mathrm{mM} \mathrm{MgCl}, 0.3 \mu \mathrm{M}$ of each primer, $0.3 \mathrm{mM}$ dNTP's and 1.0 U of GoTaq ${ }^{\circledR}$ DNA Polymerase $\left(\right.$ Promega $^{\circledR}$ ). The BMPRIB and GDF9 genes were PCR amplified under the following conditions: 5 min at $95^{\circ} \mathrm{C}$ for initial denaturation, followed by 35 cycles of $94{ }^{\circ} \mathrm{C}$ for $30 \mathrm{~s}, 60^{\circ} \mathrm{C}$ for $30 \mathrm{~s}, 72^{\circ} \mathrm{C}$ for $45 \mathrm{~s}$ and a final step of $72{ }^{\circ} \mathrm{C}$ on a PeqSTAR thermocycler $\left(\right.$ Peqlab $\left.^{\circledR}\right)$. The PCR products were analyzed by electrophoresis on $1.5 \%$ low-melting agarose gels (Promega ${ }^{\circledR}$ ). A prominent DNA band of $400-800 \mathrm{bp}$ from each reaction was excised from the gel and purified using the PureLink Quick Gel Extraction Kit (Invitrogen). The PCR products were cloned into the $\mathrm{pCR}^{\circledR}-\mathrm{TOPO}^{\circledR}$ Vectors 
(Invitrogen) via TA cloning and transformed into electro-competent $E$. coli cells DH5 $\alpha$ (Invitrogen). Three clones of each sample were randomly selected for cDNA purification and sequencing in both directions with M13 primers. Plasmids were purified using the Wizard Plus SV Minipreps DNA Purification Systems (Promega) and were sequenced using the dideoxy chain termination method on a 3730xl DNA Analyzer (Applied Biosystems) at the Laboratorio Nacional de Genómica para la Biodiversidad, CINVESTAV-Irapuato (Irapuato, Gto., Mexico).

\section{Sequence analysis}

The ORFs of the cloned cDNA sequences corresponding to the mature protein were predicted using the ExPASy ORF Finder. Multiple amino acid sequence alignment was performed using the default settings on the ClustalW2 server at EMBL-EBI.

\section{Results and discussion}

A BLAST database homology search (NCBI) showed that the GDF9 and BMP1B sequences obtained in this study share a $99 \%$ and $100 \%$ homology with the GDF9 and BMP1B genes, respectively, of other sheep breeds (Table 1). Twenty partial nucleotide sequences corresponding to the GDF9 and BMPRIB genes encode for amino acid sequences. The codons were identified by comparison with those previously found to cause mutations in other prolific breeds.

Table 1. Percent homology between the GDF9 and BMPR1B nucleotide sequences from two breeds of sheep.

\begin{tabular}{lccc}
\hline Gene & Identity (\%) & Organism & Accession number \\
\hline GDF9 & 100 & Ovis aries & NM_001142888.2 \\
GDF9 & 100 & Ovis aries & AF078545.2 \\
GDF9 & 99 & Ovis aries & HE866499.1 \\
GDF9 & 99 & Ovis aries & FJ429111.1 \\
GDF9 & 99 & Ovis aries & JN680860.1 \\
BMPR1B & 100 & Ovis aries & AF312016.1 \\
BMPR1B & 100 & Ovis aries & AF298885.1 \\
BMPR1B & 100 & Ovis aries & NM_001009431.1 \\
BMPR1B & 100 & Capra hircus & JN100106 \\
\hline
\end{tabular}

In position 332 of the GDF9 ORF, the GGT codon is expressed and codes for the Val residue. This codon corresponds to the non-carrier allele containing the G6 mutation. The GTG codon is expressed at position 371 and codes for the Val residue, corresponding to the non-carrier allele containing the G7 mutation. Codon TCT was found in position 395 and codes for the Ser residue, which corresponds to the non-carrier allele containing the G8 mutation (Figure 1).

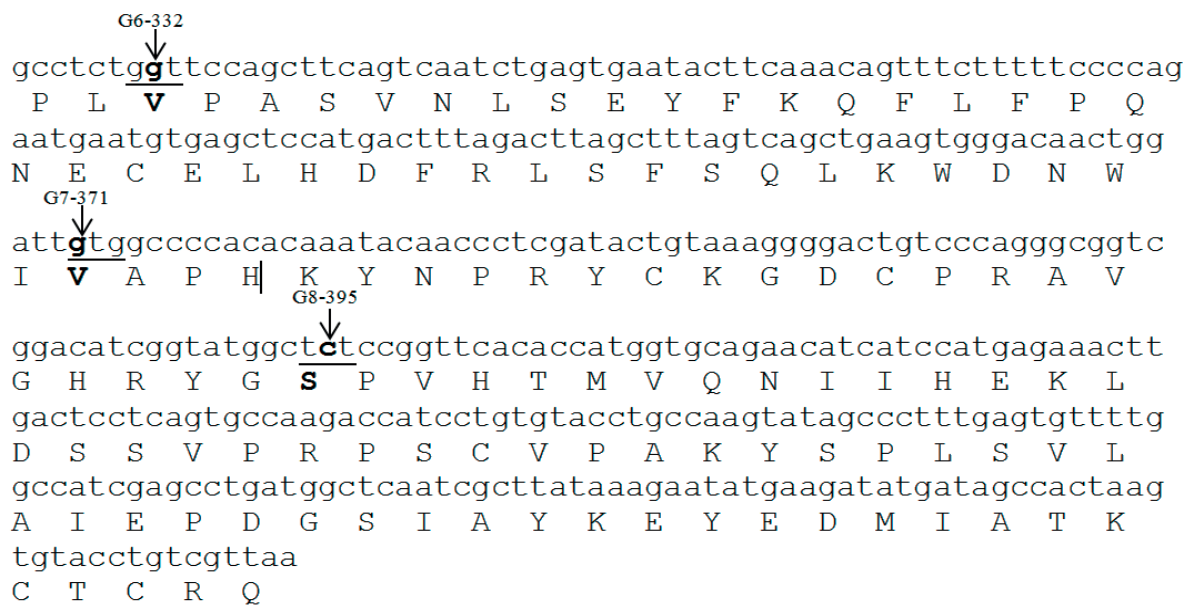

Figure 1. Consensus sequence predicting the partial ORF of GDF9. Underlined letters indicate the codon variants for the G6, G7 and G8 mutations. Lowercase black letters indicate the nucleotide variants and capital letters indicate the respective amino acid residues. 
In the Blackbelly breed, the FecB mutation in BMPR1B contains a CAG codon that codes for $\mathrm{Q}$ at position 249 of the amino acid sequence, the non-carrier allele (Figure 2). In several breeds, a substitution in the $\mathrm{G} \rightarrow \mathrm{A}$ nucleotide has been reported, where changes result in the amino acid residue changes $\mathrm{R} \rightarrow \mathrm{H}(\mathrm{G} 1), \mathrm{V} \rightarrow \mathrm{I}(\mathrm{G} 6), \mathrm{V} \rightarrow \mathrm{M}(\mathrm{G} 7)$, while substitution in the $\mathrm{C} \rightarrow \mathrm{T}$ nucleotide result in the amino acid residue changes $\mathrm{S} \rightarrow \mathrm{F}$ (G8). These mutations change the ORF of the GDF9 gene and occur in the mature protein, affecting its biological activity. The $\mathrm{FecG}^{\mathrm{H}}(\mathrm{G} 8)$ mutation found in the Belclare and Cambridge sheep is situated in the protein region implicated in the union of the BMPR1B protein with the type I receptor, which affects the linking-to-receptor capacity and causes an increase in the ovulation rate in sheep; $\mathrm{FecG}^{\mathrm{H}}$ homozygotes are sterile (Hanrahan et al., 2004). Recently, Mullen et al. (2013) have shown that the Lleyn and Finnish Landrace breeds are the ancestors of the Belclare and Cambridge breeds, respectively. The Lleyn breed is the source of the G8 mutation, which results in the high prolificacy of the Belclare and Cambridge breeds. The reported G1 mutation has been investigated, as it is linked to the prolificacy of the Asian breed Garole (Polley et al., 2010). Mutations in the GDF9 gene have not been identified in prolific sheep or goat breeds. In the Black Bengal goat, only wild type alleles were identified as having G, A, G, $\mathrm{G}$ and $\mathrm{C}$ nucleotides at the G1, G4, G6, G7 and
G8 locations, which correspond to the Arginine, Glutamic acid, Valine and Serine amino acids, respectively. All animals in this study were wildtype homozygous for GDF9 (Polley et al., 2009). Results from the GDF9 analysis in the Blackbelly breed are congruent with the results of mutation analysis in G5, G6, G7 and G8 from different North African sheep breeds (Barbarine, Queue Fine de L'Ouest, Noire de Thibar, Sicilo-Sarde and D'man). Each of these breeds are homozygotic for these mutations, and the congruence at the GDF9 locus may be due to the phylogenetic relatedness of Blackbelly ewes and these breeds.

A transition from $A \rightarrow G$ in BMPRIB has been reported in many breeds, including the Small Tailed Han (Chu et al., 2007; David et al., 2006) and the $\mathrm{Hu}$ (David et al., 2006; Guan et al., 2007). This mutation results in a change in the amino acid change from Glutamine in the wild-type allele to Arginine ( $\mathrm{CAG} \rightarrow \mathrm{CGG}$ ), indicating that heterozygous sheep carry the FecB mutation found in Booroola Merino ewes (Wilson et al., 2001).

The absence of the FecB mutation has also been reported in the following prolific breeds from different countries: Romanov (Canada), Chios (Cyprus), Tyrolian Mountain Sheep (Austria), Teeswater (England), Bluefaced Leicester (Scotland), D’Man (Morocco), Loa (Iceland), East Friesian (Germany), Romanov (Germany), white

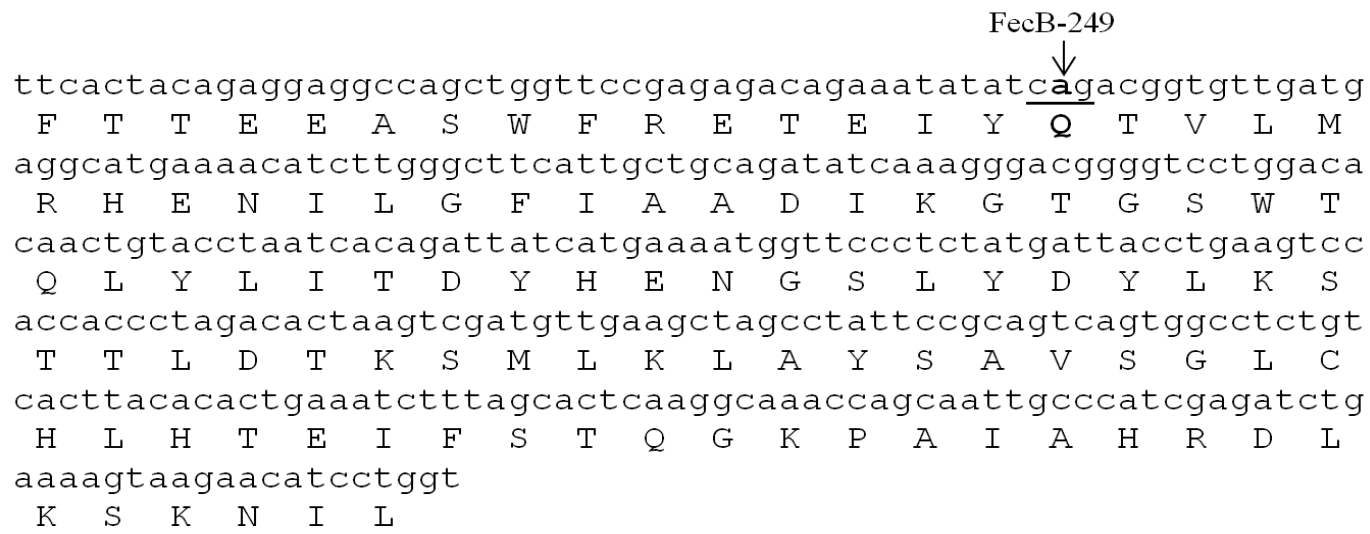

Figure 2. Consensus sequence to predict the partial ORF of BMPR1B. Underlined letters indicate the codon variants for FecB mutations. Lowercase black letters indicate the nucleotide variants and capital letters indicate the respective amino acid residues. 
and brown Mountain Sheep (Germany), German White-Headed Mutton (Germany), Finn (Ireland), Lleyn (Ireland), Galician (Spain) and St. Croix (USA) (Davis et al., 2006). The absence of the $\mathrm{FecB}$ gene in the present study is in concordance with the investigation of Davis et al. (2006), which reports that the Blackbelly breed has a mean litter of 2.3. In another African breed, the absence of the FecB mutation has also been reported (Abulyazid et al., 2011).

In conclusion, mutations affecting prolificacy were not found in the cDNA of either GDF9 or
BMPRIB. It is possible that high prolificacy is a main characteristic of the hairy breeds. However, the high prolificacy rate shown may be regulated by other genes that have not yet been explored in sheep breeds.

\section{Acknowledgements}

This investigation was supported by Grant: 4540.12-P (to Roberto Zamora Bustillos) from Dirección General de Educación Superior Tecnológica (DGEST).

\section{Resumen}

R.B. López-Ramírez, H.F. Magaña-Sevilla, R. Zamora-Bustillos, J.P. Ramón-Ugalde y D. González-Mendoza. 2014. Análisis de la región 3' terminal de los genes GDF9 y BMPR1B en ovejas Blackbelly de Yucatán, México. Cien. Inv. Agr. 41(1): 123-128. La mutación FecB del gen BMPR1B es conocido como "Boorola", y fue identificada por primera vez en la oveja Merino; las mutaciones G6, G7 y G8 están localizadas en el gen GDF9 y han sido identificadas en varias razas de ovejas, entre ellas, Belclare y Cambridge. La raza de ovinos, conocida como Blackbelly, está bien adaptada a climas tropicales, debido a su origen africano, y el tamaño de su camada al nacimiento es de 2 a 3 corderos. El objetivo de la presente investigación consistió en la identificación de mutaciones en la región 3' del cDNA de los genes GDF9 y BMPR1B, en 20 ovejas multíparas Blackbelly. Los resultados indican la ausencia de estas mutaciones en dicha raza; sin embargo, es importante analizar la región $5^{`}$ del cDNA de estos genes, para descartar la ausencia o presencia de otras mutaciones ligadas a la prolificidad.

Palabras clave: Blackbelly breed, cDNA, FecB, 3' PCR-RACE.

\section{References}

Abulyazid, I., M.S. Abdalla, H.M. Sharada, H. M. Saleh, and W.F. Hassanin. 2011. Prolificacy Detection in Egyptian Sheep using RFLP-Specific PCR. Egyptian Academic Journal of Biological Science 1:1-4.

Bodensteiner, K.J., C.M. Clay, C.L. Moeller, and H.R Sawyer. 1999. Molecular cloning of the ovine Growth/Differentiation Factor-9 gene and expression of growth/differentiation factor-9 in ovine and bovine ovaries. Biology Reproduction 60:381-386.

Chu, M-X., Z.H. Liu, C.L. Jiao, Y.Q. He, L. Fang, S.C. Ye, G.H. Chen, and J.Y Wang. 2007. Mutations in BMPR1B and BMP-15 genes are associated with litter size in Small Tailed Han sheep (Ovis aries). Journal of Animal Science 85:598603.

Davis, G.H., L. Balakrishnan, I.K. Ross, T. Wilson, S.M Galloway, B.M. Lumsden, J.P. Hanrahan, M. Mullen, X.Z. Mao, G.L. Wang, Z.S. Zhao, Y.Q. 
Zeng, J.J. Robinson, A.P. Mavrogenis, C. Papachristoforou, C. Peter, R. Baumung, P. Cardyn, I. Boujenane, N.E. Cockett, E. Eythorsdottir, J.J. Arranz, and D.R. Notter. 2006. Investigation of the Booroola $(\mathrm{FecB})$ and Inverdale $(\mathrm{FecX}) \mathrm{mu}-$ tations in 21 prolific breeds and strains of sheep sampled in 13 countries. Animal Reproduction Science 92:87-96.

Davis, G.H., S.M. Galloway, I.K. Ross, S.M. Gregan, J. Ward, B.V. Nimbkar, P.M. Ghalsasi, C. Nimbkar, G.D. Gray, Subandriyo, I. Inounu, B. Tiesnamurti, E. Martyniuk, E. Eythorsdottir, P. Mulsant, F. Lecerf, J.P. Hanrahan, G.E. Bradford, and T. Wilson. 2002. DNA tests in prolificy sheep from eight countries provide new evidence on origin of the Booroola (FecB) mutation. Biology of Reproduction 66:1869-1874.

Guan, F., L. Shou-Ren, S. Guo-Qing, and Y. Li-Guo. 2007. Polymorphism of FecB gene in nine sheep breeds or strains and its effects on litter size, lamb growth and development. Animal Reproduction Science 99: 44-52.

Hanrahan, J.P., S.M. Gregan, P. Mulsant, M. Mullen, G.H. Davis, R. Powell, and S.M. Galloway. 2004. Mutations in the genes for oocyte-derived growth factors GDF9 and BMP15 are associated with both increased ovulation rate and sterility in Cambridge and Belclare sheep (Ovis aries) Biology of Reproduction 70:900-909.

Hua, G.H, and L.G. Yang. 2009. A review of research progress of FecB gene in Chinese breeds of sheep, Biology of Reproduction 116:1-9.

McClean L., L. Waterman, and C. Robert. 2011. Genetic analysis of three populations of Barbados Blackbelly sheep at microsatellite loci. Journal of Agricultural Science and Technology A1:187-1191.

Mullen, M.P., J.P. Hanrahan, D.J. Howard, and R. Powell. 2013. Investigation of prolific sheep from UK and Ireland for evidence on origin of the mutations in BMP15 $\left(\mathrm{FecX}^{\mathrm{G}}, \mathrm{FecX}^{\mathrm{B}}\right)$ and GDF9 $\left(\mathrm{FecG}^{\mathrm{H}}\right)$ in Belclare and Cambridge sheep. PLoS ONE 8(1):e53172.
Mulsant, P., F. Lecerf, S. Fabre, L. Schibler, P. Monget, I. Lanneluc, C. Pisselet, J. Riquet, D. Monniaux, I. Callebaut, E. Cribiu, J. Thimonier, J. Teyssier, L. Bodin, Y. Cognié, N. Chitour, and J.M. Elsen. 2001. Mutation in bone morphogenetic protein receptor $1 \mathrm{~B}$ is associated with increased ovulation rate in Booroola Merino ewes. Proceedings of the National Academy of Sciences of the United States of America 9:5104-5109.

Polley, S., S. De, S. Batabyal, R. Kaushik, P.Yadav, J.S. Arora, S. Chattopadhyay, S. Pan, B. Brahma, T.K. Datta, and S.L. Goswami. 2009. Polymorphism of fecundity genes (BMPR1B, BMP15 and GDF9) in the Indian prolific Black Bengal goat. Small Ruminant Research 85:122-129.

Polley, S., S. De, B. Brahma, A. Mukherjee, P.V. Vinesh, S. Batabyal, J.S. Arora, S. Pan, A.K. Samanta, and T.K. Datta, S.L. Goswami. 2010. Polymorphism of BMPR1B, BMP15 and GDF9 fecundity genes in prolific Garole sheep. Tropical Animal Health and Production 42(5):985-993.

Souza, C.J., C. Macdougall, B.K. Campbell, A.S. Mcneilly, and D.T. Baird. 2001. The Booroola (FecB) phenotype is associated with a mutation in the bone Morphogenetic receptor type 1B (BMPR1B) gene. Journal of Endocrinology 169:R1-R6.

Wang, G.L., X.Z. Mao, G.H. Davis, Z.S. Zhao, L.J. Zhang, and Y.Q. Zeng. 2003. DNA tests in $\mathrm{Hu}$ sheep and Han sheep (small tail) showed the existence of Booroola (FecB) mutation. Journal of Nanjing Agricultural University 1:104-106.

Wilson, T., X.Y. Wu, J.L. Juenge, I.K. Ross, J.M. Lumsden, E.A. Lord, K.G. Dodds, G.A. Walling, J.C. Mcewan, A.R. O'Connell, K.P. Mcnatty, and G.W. Montgomery. 2001. Highly prolific Booroola sheep have a mutation in the intracellular kinase domain of bone morphogenetic protein $1 \mathrm{~B}$ receptor (ALK-6) that is expressed in both oocytes and granulose cells. Biology Reproduction 64:1225-1235. 